\title{
Obesity management for the gastroenterologist
}

\author{
Saleem Ansari (D) , ${ }^{1}$ Hasan Haboubi, ${ }^{2}$ Nadim Haboubi ${ }^{3}$
}

- Additional material is published online only. To view please visit the journal online (http://dx.doi.org/10.1136/ flgastro-2019-101391).

${ }^{1}$ Clinical Biochemistry, King's College Hospital NHS Foundation Trust, London, UK

${ }^{2}$ Gastroenterology Department, Guy's and St Thomas' NHS Foundation Trust, London, UK ${ }^{3}$ Department of Clinical Nutrition, University of South Wales, Pontypridd, UK

\section{Correspondence to} Dr Saleem Ansari, Clinical Biochemistry, King's College Hospital NHS Foundation Trust, London SE5 9RS, UK; saleem. ansari@nhs.net

Received 30 December 2019 Revised 17 March 2020

Accepted 18 March 2020 Published Online First 27 April 2020

\section{Check for updates}

(C) Author(s) (or their employer(s)) 2021. No commercial re-use. See rights and permissions. Published by BMJ.

To cite: Ansari S,

Haboubi H, Haboubi N.

Frontline Gastroenterology

2021;12:235-245.

\begin{abstract}
Obesity has reached epidemic levels in the United Kingdom. Obesity is associated with important gastrointestinal and hepatic complications which are common and can present sooner than cardiometabolic disease but often the underlying obesity remains untreated. Given that gastroenterologists and hepatologists will be at the forefront of obesity management we present an overview encompassing obesity pathophysiology, medical and surgical treatment options as well as the role of endobariatrics and the gut microbiome.
\end{abstract}

\section{INTRODUCTION}

Obesity has reached epidemic levels in the United Kingdom (UK) affecting both the adult and paediatric population. Carrying excess body weight is the norm in the UK as approximately one in four adults are obese and one in three are overweight as defined by body mass index (BMI, table 1). ${ }^{1}$ Ethnic differences for BMI ranges defining overweight and obesity exist especially between Caucasian and Asian populations (table 1), reflecting the higher risk of cardiometabolic disease at a lower BMI in the latter population. ${ }^{2}$ The UK has the second highest prevalence of obesity in Europe and sixth highest worldwide. The National Health Service (NHS) spent approximately $£ 6.3$ billion on overweight and obesity-related illness in $2014 / 2015$ and this is predicted to rise to $£ 9.7$ billion by $2050 .^{1}$

\section{Complications of obesity}

The excess adiposity that characterises obesity is associated with significant morbidity and mortality. An observational study involving 2.8 million UK adult's between January 2000 and July 2018 showed that individuals with a BMI between $40-45 \mathrm{~kg} / \mathrm{m}^{2}$, when compared with normal weight individuals, had a $50 \%$ increased risk of all-cause mortality, a 12-times higher risk of type 2 diabetes mellitus (T2DM) and were 22 times more likely to develop obstructive sleep apnoea (OSA). The least obese (BMI $30-35 \mathrm{~kg} /$ $\mathrm{m}^{2}$ ) had a $70 \%$ greater risk of heart failure and were five times more likely to develop T2DM and OSA. ${ }^{3}$

A population-based cohort study involving 3.6 million UK adults demonstrated that cardiovascular disease and cancer were important causes of mortality among overweight and obese patients, ${ }^{4}$ and obesity is the second biggest preventable cause of cancer in the UK. ${ }^{5}$ Obesity is also associated with significant psychological comorbidity including binge eating, emotionally driven eating, anxiety and mood disorders. ${ }^{6}$ Addressing obesity stigmatisation and discrimination is crucial so that patients and healthcare providers appreciate obesity as a disease that requires treatment.

\section{Gastrointestinal complications of obesity}

Obesity is associated with common gastrointestinal and hepatic complications (table 2) that often present sooner than cardiometabolic diseases ${ }^{7}$ and therefore gastroenterologists and hepatologists have a unique opportunity to implement early weight loss interventions and/or to refer to specialist weight management centres. Abdominal obesity is implicated in oesophageal, hepatobiliary and malignant disorders (table 2) and it is best captured by measuring waist circumference $^{7}$. Indeed, abdominal obesity is also an important predictor of non-alcoholic fatty liver disease (NAFLD) even among patients with a normal BMI .

\section{Pathophysiology}

In the past 50 years, $20 \%-30 \%$ of entire populations have become obese due to environmental changes encouraging increased energy intake and reduced energy expenditure. ${ }^{8}$ The availability of large portions of highly palatable 


\section{Specialty certificate exam style BEST-OF-FIVE questions}

\section{Question 1}

A middle-aged female with a past medical history of obesity and diabetes underwent a laparoscopic Roux-en-Y gastric bypass 1 week ago. She presents to the acute medical take with a fall on a background of a 2-day history of persistent vomiting, confusion and blurred vision.

What micronutrient is most likely to be deficient?
a. Vitamin $B_{1}$
b. Vitamin $B_{6}$
c. Vitamin $B_{12}$
d. Calcium
e. Potassium
Correct answer a) Vitamin $B_{1}$ (Thiamine)

The presentation suggests developing Wernicke's encephalopathy following a recent gastric bypass which places this patient at increased risk of thiamine deficiency because this water-soluble vitamin is absorbed in the duodenum and proximal jejunum. Thiamine can only be obtained from the diet and cannot be endogenously synthesised by human cells.

\section{Question 2}

A middle-aged female who is asymptomatic is referred to a joint hepatology-diabetology clinic with liver steatosis on abdominal ultrasound, normal liver function tests and a glycated haemoglobin $(\mathrm{HbA1C})$ of $59 \mathrm{mmol} / \mathrm{mol}$. She has a past medical history of treated bladder cancer and type 2 diabetes mellitus. She is a non-smoker and does not drink alcohol. She is currently taking metformin $1 \mathrm{~g}$ twice a day and gliclazide $80 \mathrm{mg}$ twice a day. On examination, herwaist circumference is $102 \mathrm{~cm}$ and body mass index (BMI) is $37 \mathrm{~kg} / \mathrm{m}^{2}$. Her liver screen is unremarkable. She is commenced on a once weekly subcutaneous injection of semaglutide.

What drug class does semlaglutide belong to?

a. Glucagon-like peptide 1 agonist

b. Dipeptidyl peptidase-4 inhibitor

c. Sodium-glucose cotransporter 2 inhibitor

d. Insulin secretagogues

e. Biguadines

Correct answer: a) Glucagon-like peptide 1 agonist (GLP-1)

Semaglutide is a GLP-1 agonist that has effects on the central nervous system, pancreas and intestinal tract. GLP-1 agonists can mediate an incretin effect whereby insulin secretion is enhanced when enteral glucose is given in comparison to parenteral glucose. GLP-1 agonists can have trophic effects on pancreatic beta-cells and are assocaited with increased satiety, reduced food intake and weight loss. GLP-1 suppresses appetite through vagal-dependent and vagal-independent mechnaism, the latter involving activation of POMC/CART (pro-opiomelanocortin/cocaine and amphetamine regulated transcript) hypothalamic neurones. GLP-1 also delays gastric emptying.

\section{Question 3}

A middle-aged male presents to your gastroenterology outpatient clinic. He underwent a Roux-en-Y gastric bypass operation for Obesity Class II (BMI 35-39 kg/m²) and type 2 diabetes 12 months ago. He has lost $40 \mathrm{~kg}$ since his operation and his current glycated haemoglobin is $6 \%$. He complains of nausea, abdominal pain, diarrhoea, tremors, sweating and palpitations, especially within 30 minutes of eating sugary snacks for the past 1 month.

What is the most appropriate management option for this patient?

a. Inpatient surgical review

b. Advise a low glycaemic index carbohydrate diet

c. Prescribe antibiotics

d. Reassure and advise Fermentable Oligo-, Di-, Mono-saccharides And Polyols (FODMAP) diet

e. Colestyramine

Correct answer: b) Advise a low glycaemic index carbohydrate diet

The question gives a history of dumping syndrome which can affect up to $50 \%$ of patients at some stage following gastric bypass. It is caused by rapid emptying of gastric contents into the small intestine. This causes fluid to shift into the small intestine due to increased osmolarity . Some patients may also experience an exaggerated postprandialinsulin response which can cause hypoglycaemic episodes, especially after eating high glycaemic index carbohydrates and/or eating too fast. Mainstay of management is to adhere to a low GI carbohydrate diet and to eat small frequent meals. Medications such as diazoxide, octreotide or calcium channel antagonists are availabe for refractory cases of dumping syndrome. GLP-1 analogues have also been trialled as partial agonists. 
Table 1 Classification of weight according to BMI for Caucasian, South Asian and Chinese populations ${ }^{1}$

\begin{tabular}{lll}
\hline & \multicolumn{1}{c}{ BMI $\left(\mathrm{kg} / \mathrm{m}^{2}\right)$} \\
\cline { 2 - 3 } Classification & \multicolumn{2}{c}{$\begin{array}{l}\text { Couth Asian*asian } \\
\text { Chinese }\end{array}$} \\
\hline Healthy or 'normal' weight & $18.5-24.9$ & $18.5-23$ \\
Overweight or preobesity & $25-29.9$ & $23-27.5$ \\
Obesity I & $30-34.9$ & $\geq 27.5$ \\
Obesity II & $35-39.9$ & \\
Obesity III & $\geq 40$ & \\
\hline
\end{tabular}

*South Asian = Bangladesh, Bhutan, India, Indian-Caribbean (immigrants of South Asian family origin), Maldives, Nepal, Pakistan and Sri Lanka BMI, body mass index. energy-dense processed foods are a key driver for weight gain. Food intake is influenced by external variables such as food palatability and availability and the internal gut-brain axis (figure 1). ${ }^{8}$ Hunger and satiety are regulated in the brain via complex reciprocal connections between the hypothalamus, brainstem and higher cortical areas which receive peripheral neuroendocrine signals from the gastrointestinal tract which regulates meal initiation and termination (table 3$)^{8}$. Insulin, leptin and adipokines are involved in the longterm regulation of energy homeostasis mediated by the amount of stored adipose tissue (table 3). ${ }^{9}$

\begin{tabular}{|c|c|c|c|}
\hline \multirow[t]{2}{*}{ Gastrointestinal disease } & \multicolumn{2}{|l|}{ Obesity as a risk factor } & \multirow[t]{2}{*}{$\begin{array}{l}\text { Physiological mechanism by which obesity is associate } \\
\text { with gastrointestinal disease }\end{array}$} \\
\hline & Risk expressed as OR or RR & $95 \% \mathrm{Cl}$ & \\
\hline \multicolumn{4}{|l|}{ Oesophagus } \\
\hline Gastro-oesophageal reflux disease & OR, 1.94 & $1.46-2.57$ & $\begin{array}{l}\uparrow \text { intra-abdominal pressure, } \downarrow \text { Oesophageal pressure. } \\
\uparrow \text { Oestrogen }\end{array}$ \\
\hline Erosive oesophagitis & OR, 1.87 & $1.51-2.31$ & Abdominal adiposity \\
\hline Barrett's oesophagus & $\mathrm{OR}, 4.0$ & $1.4-11.1$ & $\begin{array}{l}\text { Abdominal adiposity, } \\
\downarrow \text { Adiponectin, } \uparrow \text { Leptin }\end{array}$ \\
\hline Oesophageal adenocarcinoma & $\begin{array}{l}\text { Men: OR, } 2.4 \\
\text { Women: OR, } 2.1 \\
\text { RR, } 4.8\end{array}$ & $\begin{array}{l}1.9-3.2 \\
1.4-3.2 \\
3.0-7.7\end{array}$ & $\begin{array}{l}\text { Abdominal adiposity, } \downarrow \text { Adiponectin, } \\
\uparrow \text { Leptin, Insulin-like growth factor }\end{array}$ \\
\hline \multicolumn{4}{|l|}{ Stomach } \\
\hline Gastritis & OR, 2.23 & $1.59-3.11$ & $\downarrow$ Adiponectin \\
\hline Gastric cancer & $\begin{array}{l}\text { OR, } 1.55 \\
\text { RR (Cardia), } 1.8\end{array}$ & $\begin{array}{l}1.31-1.84 \\
1.3-2.5\end{array}$ & Proinflammatory, adipokines, Insulin-like growth factor \\
\hline \multicolumn{4}{|l|}{ Hepatobiliary } \\
\hline Non-alcoholic fatty liver disease & $\mathrm{RR}, 4.6$ & $2.5-11.0$ & $\begin{array}{l}\text { Abdominal obesity, } \uparrow \text { serum free fatty acids, } \uparrow \text { hepatic } \\
\text { triglycerides, hepatic de novo lipogenesis }\end{array}$ \\
\hline Liver cirrhosis & $\mathrm{RR}, 4.1$ & $1.4-11.4$ & $\begin{array}{l}\text { Non-alcoholic fatty liver disease, non-alcoholic } \\
\text { steatohepatitis, proinflammatory }\end{array}$ \\
\hline Hepatocellular carcinoma & $\mathrm{RR}, 1.8$ & $1.6-2.1$ & $\begin{array}{l}\text { Non-alcoholic fatty liver disease, non-alcoholic } \\
\text { steatohepatitis, proinflammatory }\end{array}$ \\
\hline Gallstone disease (gallstones, cholecystitis) & $\begin{array}{l}\text { Men: RR } 2.51 \\
\text { Women: RR, } 2.32\end{array}$ & $\begin{array}{l}2.16-2.91 \\
1.17-4.57\end{array}$ & $\begin{array}{l}\text { Abdominal obesity, } \uparrow \text { Insulin, } \uparrow \text { leptin, } \uparrow \text { lipids, insulin } \\
\text { resistance, dysmotility }\end{array}$ \\
\hline Gallbladder cancer & $\mathrm{RR}, 1.3$ & $1.2-1.4$ & $\uparrow$ risk of gallstones, chronic inflammation \\
\hline \multicolumn{4}{|l|}{ Pancreas } \\
\hline Acute pancreatitis & $\mathrm{RR}, 2.20$ & $1.82-2.66$ & Hyperlipidaemia, chronic inflammation \\
\hline Pancreatic cancer & $\begin{array}{l}\text { Men: RR, } 1.10 \\
\text { Women: RR, } 1.13 \\
\text { RR, } 1.5\end{array}$ & $\begin{array}{l}1.04-1.22 \\
1.05-1.18 \\
1.2-1.8\end{array}$ & Insulin-like growth factor binding protein-1 \\
\hline \multicolumn{4}{|l|}{ Intestinal } \\
\hline Diarrhoea & $\mathrm{OR}, 2.7$ & $1.10-6.8$ & $\uparrow$ Bile acids, accelerated colonic transit, \\
\hline Diverticular disease & $\mathrm{RR}, 1.78$ & $1.08-2.94$ & Chronic inflammation, alteration in gut microbiota \\
\hline Polyps & OR, 1.44 & $1.23-1.70$ & Chronic inflammation \\
\hline Colorectal cancer & $\begin{array}{l}\text { Men: RR, } 1.95 \\
\text { Women: RR, } 1.15 \\
\text { RR, } 1.3\end{array}$ & $\begin{array}{l}1.59-2.39 \\
1.06-1.24 \\
1.3-1.4\end{array}$ & $\begin{array}{l}\text { Chronic inflammation, } \uparrow \text { adipokines, bile acids, insulin } \\
\text { resistance, gut microbiota }\end{array}$ \\
\hline
\end{tabular}

Adapted from Camilleri et al. ${ }^{7}$

$\mathrm{Cl}$, confidence interval; $\mathrm{OR}$, odds ratio; $\mathrm{RR}$, relative risk. 


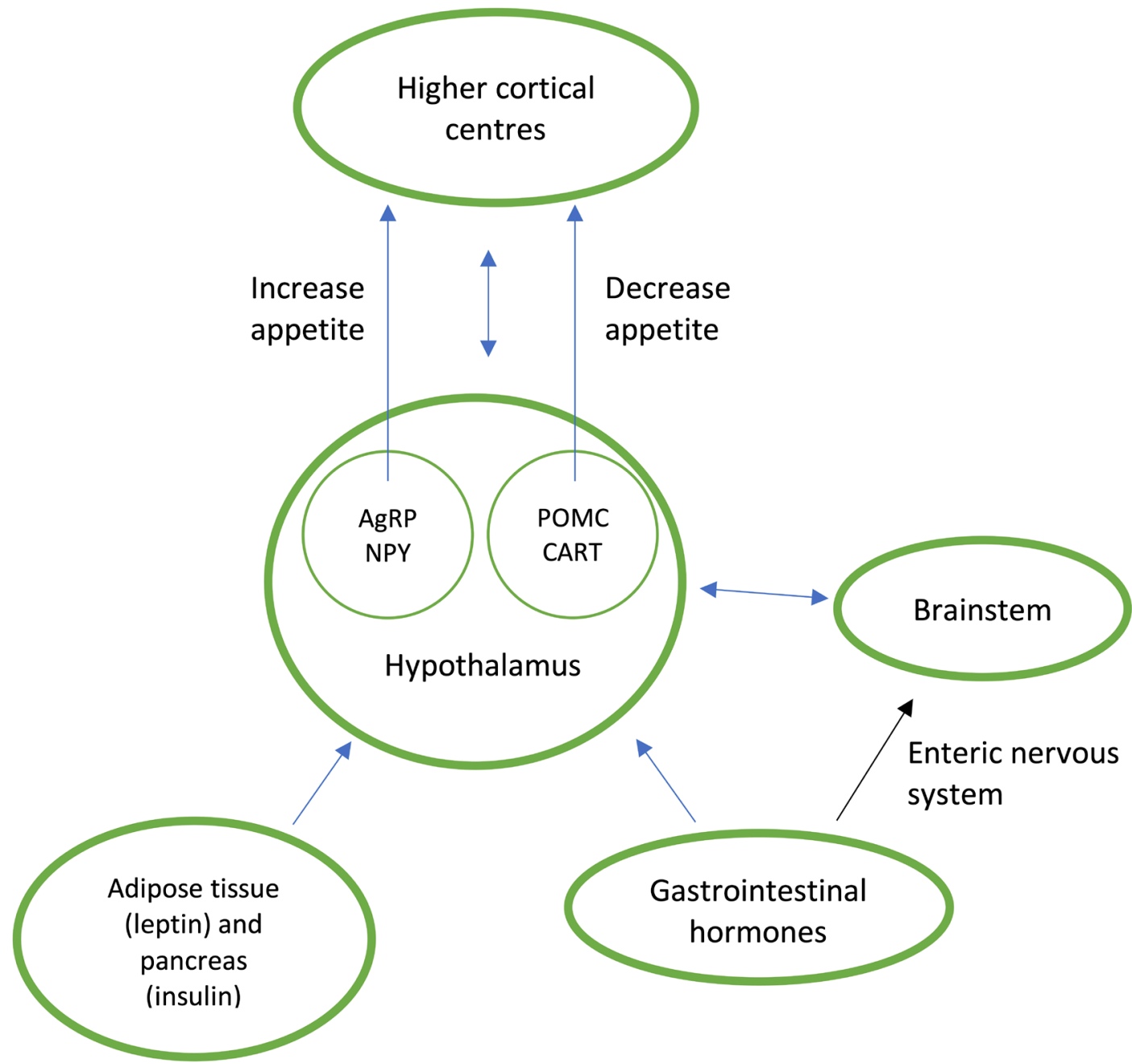

Figure 1 Neuroendocrine regulation of appetite. Gastrointestinal and peripheral hormones communicate directly (via the blood brain barrier) and indirectly (enteric nervous system) to the subconscious hypothalamus and brainstem to either stimulate appetite via agouti-related peptide (AgRP) and neuropeptide Y (NYP) or suppress appetite via pro-opiomelanocortin (POMC) and cocaine and amphetamine regulated transcript (CART). These signals are conveyed to higher conscious brain centres which regulate eating behaviour. ${ }^{8}$

\section{Management}

The multifactorial nature of obesity requires a multidisciplinary and multicomponent approach that incorporates lifestyle, medical and/or surgical intervention. The Natoinal Institute of Clinical Excellence (NICE) use risk stratification to guide treatment acknowledging that high-risk patients require more intensive treatment (table 4). ${ }^{10}$

\section{Lifestyle}

The foundation of obesity management is empowering patients with the skills and strategies to facilitate weight loss (table 5), weight loss maintenance and prevent weight regain, all of which requires different approaches and should be maintained alongside medical and surgical treatment. Psychological therapies for the treatment of obesity can be used in specialist weight management centres and include interpersonal psychotherapy, behavioural therapy and various forms of cognitive behavioural therapy which is effective for bulimia nervosa. ${ }^{11}$
Indeed, input from a clinical psychologist is absolutely necessary before proceeding to surgery. ${ }^{10}$

\section{Pharmacological}

Pharmacotherapy can be considered as an adjunct in patients who are struggling to lose weight (eg, $5-10 \%$ after 3-6 months) or maintain weight loss with lifestyle interventions. ${ }^{10}$ Orlistat tablets ${ }^{10}$ and liraglutide (Saxenda) injections ${ }^{12}$ are currently the only medications licenced for the treatment of obesity in the UK, while naltrexone plus bupropion combination is approved by the European Medicines Agency but currently unavailable in the UK (table 6). Patients who fail to lose 5\% of their body weight after 12 weeks with orlistat or liraglutide should discontinue use. ${ }^{10}$ Like liraglutide, metformin and sodium-glucose cotransporter-2 (SGLT-2) inhibitors are medications used to treat type 2 diabetes which are assocaited with weight loss but neither are licenced for the treatment of obesity. ${ }^{12}$ None of antiobesity drugs are 
Table 3 Summary of the action of selected gastrointestinal hormones, insulin and leptin and how they are altered in obesity ${ }^{9}$

\begin{tabular}{|c|c|c|c|c|}
\hline Gut hormone & $\begin{array}{l}\text { Gastrointestinal site of } \\
\text { secretion }\end{array}$ & $\begin{array}{l}\text { Action on gastrointestinal } \\
\text { system }\end{array}$ & Effect on appetite & Changes in obesity \\
\hline Ghrelin & $\mathrm{X} / \mathrm{A}$-cells in gastric fundus & Increases gastric motility & Increases appetite & $\begin{array}{l}\text { Reduced pre-prandial } \\
\text { peak levels and reduced } \\
\text { postprandial suppression }\end{array}$ \\
\hline Peptide $Y Y_{3-36}$ & L-cells in distal intestine & $\begin{array}{l}\text { Inhibits gallbladder secretions, } \\
\text { inhibits gastric emptying, } \\
\text { inhibits pancreatic secretions, } \\
\text { enterogastrone effect. }\end{array}$ & Decreases appetite & $\begin{array}{l}\text { Reduced fasting and } \\
\text { postprandial secretion }\end{array}$ \\
\hline Glucagon-like peptide-1 & L-cells in distal intestine & $\begin{array}{l}\text { Inhibits gastric emptying, inhibits } \\
\text { gastric secretions, promotes } \\
\text { pancreatic beta-cell growth, } \\
\text { incretin effect. }\end{array}$ & Decreases appetite & $\begin{array}{l}\text { Reduced postprandial } \\
\text { secretion }\end{array}$ \\
\hline Oxyntomodulin & L-cells in distal intestine & $\begin{array}{l}\text { Inhibits gastric secretions, } \\
\text { inhibits gastric emptying, incretin } \\
\text { effect. }\end{array}$ & Decreases appetite & - \\
\hline Cholecystokinin & $\begin{array}{l}\text { I cells in small intestine, co- } \\
\text { localises with PYY in L-cells of } \\
\text { distal intestine }\end{array}$ & $\begin{array}{l}\text { Promotes gallbladder } \\
\text { contraction, increases pancreatic } \\
\text { secretions, inhibits gastric } \\
\text { secretions, inhibits gastric } \\
\text { emptying. }\end{array}$ & Decreases appetite & Not implicated \\
\hline Peripheral hormone & Site of secretion & Effect on appetite & \multicolumn{2}{|c|}{ Changes in obesity } \\
\hline Insulin & Pancreas (beta-cells) & Decreases appetite & \multicolumn{2}{|c|}{ Hyperinsulinaemia, insulin resistance } \\
\hline Leptin & Adipocytes & Decreases appetite & \multicolumn{2}{|c|}{ Hyperleptinaemia, leptin resistance } \\
\hline
\end{tabular}

licenced in pregnancy and therefore women of childbearing age should use contraception if these medications are prescribed. ${ }^{10}$

\section{Bariatric/metabolic surgery}

Randomised controlled trials (RCTs) and prospective cohort studies provide evidence that bariatric surgery is superior to non-surgical interventions for durable weight loss and improvements in comorbidities such as type 2 diabetes, which has led to the term metabolic surgery. ${ }^{13}$ The Swedish Obese Subjects Study, a landmark cohort study involving 4047 obese patients
$\left(\mathrm{BMI}>34 \mathrm{~kg} / \mathrm{m}^{2}\right)$ demonstrated a $23 \%$ reduction in body weight 20 years after bariatric surgery when compared with conventional non-surgical management. ${ }^{14}$ Two large multicentre RCTs involving lifestyle interventions (Diabetes Prevention Programme, Look AHEAD trial) achieved 7-8 kg weight loss after 1 year, which was regained after 10 years ${ }^{13}$.

Response to bariatric surgery is variable and operation specific but Roux-en-Y gastric bypass (RYGB) and vertical sleeve gastrectomy (VSG) can achieve clinically significant weight loss and metabolic improvements

\begin{tabular}{|c|c|c|c|c|}
\hline \multirow[t]{4}{*}{ BMI $\left(\mathrm{kg} / \mathrm{m}^{2}\right)$} & \multicolumn{3}{|c|}{ Waist circumference (cm) } & \multirow[t]{4}{*}{ Comorbidity present* } \\
\hline & Low risk & High risk & Very high risk & \\
\hline & $<94$ (male) & 94-102 (male) & $>102$ (male) & \\
\hline & $<80$ (female) & 80-88 (female) & $>88$ (female) & \\
\hline Overweight (25-29.9) & 1 & 2 & 2 & 3 \\
\hline \multicolumn{5}{|l|}{$(30-34.9)$} \\
\hline $\begin{array}{l}\text { Obesity II } \\
(35-39.9)\end{array}$ & 3 & 3 & 3 & 4 \\
\hline \multicolumn{5}{|l|}{$(40+)$} \\
\hline $\begin{array}{l}1=\text { general advice on hez } \\
2=\text { diet and physical acti } \\
3=\text { diet and physical acti } \\
4=\text { diet and physical acti } \\
{ }^{*} \text { At least one of the follc } \\
\text { apnoea polycystic ovaria } \\
\text { BMI, body mass index. }\end{array}$ & $\begin{array}{l}\text { d lifestyle. } \\
\text { edications. } \\
\text { edications; cons } \\
\text { lities should be } \\
\text { teoarthritis. }{ }^{10}\end{array}$ & $\begin{array}{l}\text { ery. } \\
\text { uch as type } 2 \text { diabe }\end{array}$ & hypertension, & ia, ischaemic heart disease, obstructive sleep \\
\hline
\end{tabular}


Table 5 Summary of NICE guidelines for weight loss through lifestyle changes with selected practical suggestions ${ }^{10}$

\begin{tabular}{|c|c|c|}
\hline & Goal & Practical suggestions \\
\hline \multirow[t]{5}{*}{ Diet } & $\begin{array}{l}600 \mathrm{kcal} / \text { day reduction } \\
\text { in energy intake }\end{array}$ & $\begin{array}{l}\text { Encourage a diet rich } \\
\text { in colourful vegetables, } \\
\text { fruits, beans, pulses, } \\
\text { wholegrains and fish }\end{array}$ \\
\hline & (Men: 1900kcal/day & $\begin{array}{l}\text { Increase the proportion } \\
\text { of high-fibre or } \\
\text { wholegrain foods }\end{array}$ \\
\hline & Women: 1400kcal/day) & $\begin{array}{l}\text { Avoid takeaway and } \\
\text { processed foods }\end{array}$ \\
\hline & & $\begin{array}{l}\text { Avoid sugary drinks and } \\
\text { replace them with water } \\
\text { or drinks with no or low } \\
\text { sugar }\end{array}$ \\
\hline & & $\begin{array}{l}\text { Avoid energy-dense } \\
\text { snacks (biscuits, } \\
\text { chocolates, cakes) }\end{array}$ \\
\hline \multirow[t]{7}{*}{ Physical activity } & $\begin{array}{l}\text { Weight neutral: } 30 \text { mins/ } \\
\text { day } 5 \text { days a week }\end{array}$ & Brisk walking or running \\
\hline & $\begin{array}{l}\text { Weight loss: } 45- \\
60 \text { mins/day }\end{array}$ & $\begin{array}{l}\text { Stair climbing, avoid } \\
\text { escalators and lifts }\end{array}$ \\
\hline & $\begin{array}{l}\text { Weight loss } \\
\text { maintenance: 60- } \\
90 \text { mins/day }\end{array}$ & Cycling \\
\hline & & Gardening \\
\hline & & $\begin{array}{l}\text { Supervised exercise } \\
\text { programme }\end{array}$ \\
\hline & & Swimming \\
\hline & $\begin{array}{l}\text { Reduce sedentary } \\
\text { behaviour }\end{array}$ & $\begin{array}{l}\text { Reduce the amount of } \\
\text { time spent sat down, } \\
\text { watching TV, using a } \\
\text { computer or playing } \\
\text { video games }\end{array}$ \\
\hline \multirow[t]{6}{*}{ Behavioural } & Self-monitoring & $\begin{array}{l}\text { Record calorie intake of } \\
\text { foods and drinks, record } \\
\text { weight loss, slow down } \\
\text { the speed of eating }\end{array}$ \\
\hline & & $\begin{array}{l}\text { Set goals based on what } \\
\text { foods to eat, what foods } \\
\text { to avoid, calorie intake } \\
\text { and amount of physical } \\
\text { activity }\end{array}$ \\
\hline & Goal setting & $\begin{array}{l}\text { Involve family and friends } \\
\text { to provide support }\end{array}$ \\
\hline & & Plan meals weekly \\
\hline & Social support & $\begin{array}{l}\text { Avoid or be able to } \\
\text { manage the sight or } \\
\text { smell of high-calorie } \\
\text { highly-palatable foods }\end{array}$ \\
\hline & Relapse prevention & \\
\hline
\end{tabular}

Adapted from NICE. ${ }^{10}$

(table 7$)^{15}$. There is on-going research to identify prognostic factors that may predict bariatric surgery outcomes and complications in order to select the right operation for the right patient. ${ }^{16}$

A retrospective UK cohort study in 2016 using 3039 electronic records found that RYGB and VSG are being favoured over gastric banding which is declining due to complication rates (eg, band slippage or intolerance) and the need for eventual surgery ${ }^{17}$. Biliopancreatic diversion with duodenal switch (BPD-DS) is rarely performed due to its complexity and historical high surgical morbidity and mortality as well as longterm nutritional deficiences. ${ }^{17}$ Bariatric surgery is indicated for severe or morbid obesity among patients fit for surgery and committed to lifelong lifestyle changes and specialist follow-up (Box 1 and 2) ${ }^{10}$.

\section{Anatomical description of procedures}

During RYGB, the upper part of the stomach is divided to create a small gastric pouch $(15-30 \mathrm{~mL})$ which is anastomosed to the mid-jejunum creating the roux or alimentary limb. The remaining stomach, duodenum and proximal jejunum, which form the bilopancreatic limb, are thus bypassed. Small bowel continuity is restored via a distal jejuno-jejunostomy, where the alimentary and bilopancreatic limbs join to form a common channel, where nutrient absorption occurs (figure 2). ${ }^{18}$

VSG involves excising 70-80\% of the stomach along the greater curvature to create a banana-sized gastric tube (figure 2). Historically, partial gastrectomy was the first stage of BPD-DS which is a two-stage procedure. The second stage involves dividing the small intestine

proximally at the duodenum and distally approximately $250 \mathrm{~cm}$ before the ileocaecal valve. The distal small bowel is anastomosed to the duodenum. The distal end of the excised small bowel, which contains bilopancreatic secretions, is attached approximately $100 \mathrm{~cm}$ before the ileocaecal valve thus allowing a long intestinal bypass with a short common channel for nutrient absorption (figure 2). ${ }^{18}$ Bilopancreatic diversion with or without duodenal switch is rarely performed but the single anastomosis duodeno-ileal bypass with sleeve gastrectomy is gaining in populatiry. Bariatric surgeries are currently described on their anatomical rearrangement but data from mechanistic studies suggest that these operations should be classified according to their metabolic outcomes. ${ }^{18}$

\section{Mechanisms of bariatric surgery}

Historically bariatric surgery was thought to induce weight loss through caloric restriction, nutrient malabsorption or both. Instead, substantial evidence suggests that the anatomical changes specific to RYGB and VSG differentially alter gastrointestinal signalling to the brain to reduce hunger, increase satiety and change food preferences from high-sugar and high-fat foods to healthier alternatives. It is these subconscious changes in eating behaviour that result in durable weight loss following bariatric surgery. ${ }^{16}{ }^{19}$ This complex gutendocrine-brain axis is mediated by profound changes in pathways involving gut hormones, bile acids, gut microbiota and the enteric nervous system (table 8). 
Table 6 Medications approved by the EMA for obesity. Indication, drug class, mechanism and side-effects for each medication is included. ${ }^{13}$ Risk factors include prediabetes, type 2 diabetes mellitus, hypertension, dyslipidaemia and obstructive sleep apnoea. ${ }^{10}$

\begin{tabular}{|c|c|c|c|}
\hline & Orlistat & Liraglutide (Saxenda) & Naltrexone plus bupropion \\
\hline Indication & BMI $\geq 30$ or $\geq 28 \mathrm{~kg} / \mathrm{m}^{2}$ with $\geq 1$ risk factor & BMI $\geq 30$ or $\geq 27 \mathrm{~kg} / \mathrm{m}^{2}$ with $\geq 1$ risk factor & $\mathrm{BMl} \geq 30 \mathrm{~kg} / \mathrm{m}^{2}$ or $\geq 27$ with $\geq 1$ risk factor \\
\hline Drug class & Gastric and pancreatic lipase inhibitor & Glucagon-like peptide-1 agonist & $\begin{array}{l}\text { Noradrenaline and dopamine reuptake } \\
\text { inhibitor plus opioid antagonist }\end{array}$ \\
\hline Mechanism & Reduces dietary fat absorption & Increases satiety, delays gastric emptying & Central appetite suppressant \\
\hline Side effects & $\begin{array}{l}\text { Abdominal pain, flatulence, steatorrhoea, } \\
\text { anxiety, anorectal haemorrhage, bullous } \\
\text { dermatitis, cholelithiasis, diverticulitis, } \\
\text { hepatitis, oxalate nephropathy, } \\
\text { pancreatitis, renal failure }\end{array}$ & $\begin{array}{l}\text { Nausea, vomiting, constipation, diarrhoea, dizziness, } \\
\text { gallbladder disorders, increased risk of infection, } \\
\text { insomnia, pancreatitis, tachycardia }\end{array}$ & $\begin{array}{l}\text { Nausea, vomiting, constipation, dry } \\
\text { mouth, dizziness, increased blood } \\
\text { pressure, insomnia, anxiety, agitation }\end{array}$ \\
\hline Contraindications & $\begin{array}{l}\text { Cholestasis, chronic malabsorption } \\
\text { syndrome, concomitant use with other } \\
\text { medications for weight loss }\end{array}$ & $\begin{array}{l}\text { Diabetic gastroparesis, inflammatory bowel disease, } \\
\text { severe congestive cardiac failure, } \geq 75 \text { years old, } \\
\text { obesity due to endocrinological or eating disorders, } \\
\text { concomitant use with other medications for weight } \\
\text { loss }\end{array}$ & Uncontrolled hypertension \\
\hline
\end{tabular}

BMI, body mass index; EMA, European Medicines Agency.

Glucagon-like peptide-1 (GLP-1) and peptide YY $_{3-36}$ (PYY) are two potent gut-derived appetite suppressor peptides that are elevated following RYGB and VSG and have been consistently associated with weight loss and blocking these hormones in postoperative bariatric patients leads to increased appetite, food intake and weight gain. ${ }^{19}$ Accelerated nutrient presentation to the enteroendocrine L-cells of the distal intestine is a key mechanism explaining the postoperative elevations in GLP-1 and PYY, which has been more consistently demonstrated following RYGB than VSG. Unlike RYGB, VSG has been consistently associated with reduced ghrelin but there is uncertainty whether this is a key driver facilitating weight loss. ${ }^{19}$ Following RYGB and VSG, increased bile acid concentration and altered composition are also suggested to contribute towards weight loss and improvements in postprandial glucose metabolism.$^{19}$

\section{Metabolic surgery and type 2 diabetes}

There is substantial evidence from RCTs that metabolic surgery is superior to medical therapy for the treatment and remission of type 2 diabetes (relative risk 22.1 (3.2-154.2)). There is rapid improvement in glycaemic control among obese patients following RYGB and VSG independent of weight loss and this is discussed elsewhere ${ }^{16}$.

\section{Bariatric surgery, NAFLD and non-alcoholic steatohepatitis (NASH)}

A systematic review of observational data suggest that bariatric surgery is associated with improvements in NAFLD and NASH using invasive histological and non-invasive markers (eg, NAFLD fibrosis scores). ${ }^{20}$ Weight loss is a key mechanism that mediates improvements in inflammation and glucose and lipid metabolism, in NASH and NAFLD respectively. Liver cirrhosis is a relative contraindication to bariatric surgery and large RCTs with long-term follow-up are needed before bariatric surgery can be recommended for NAFLD or NASH. ${ }^{20}$

\section{Early complications ( $<30$ days)}

The safety of bariatric surgery has improved in the past 20 years. Almost all operations are done laparoscopically,increased experience and volume of procedures along with enhanced recovery after surgery programmes have contributed to reduced operation times, length of stay and complications ${ }^{16}$. A metaanalysis of published mortality data $(\mathrm{n}=84,931)$ after bariatric surgery reported a $<30$-day mortality of $0.3 \%$ but this varies across subgroups and procedures $^{16}$ with data from the US MBSAQIP registry $(n=134,142)$ reporting that perioperative morbidity and mortality after laparoscopic VSG to be half that of

Table 7 Percentage of excess BMI lost at 1 and 5 year(s) following RYGB and VSG and percentage of patients achieving remission of comorbidites at 5 year follow-up $(n=217)^{15}$.

\begin{tabular}{|c|c|c|c|c|c|}
\hline & \multirow{2}{*}{$\begin{array}{l}\% \text { Excess BMI lost after } \\
1 \text { year }\end{array}$} & \multirow{2}{*}{$\begin{array}{l}\% \text { Excess BMI lost } \\
\text { after } 5 \text { years }\end{array}$} & \multicolumn{3}{|c|}{$\begin{array}{l}\% \text { of patients acheiving remission of comorbidity } \\
\text { at } 5 \text { years }\end{array}$} \\
\hline & & & T2DM & Dyslipidaemia & Hypertension \\
\hline RYGB & 76.70 & 68.30 & 67.90 & 62.30 & 70.30 \\
\hline VSG & 72.40 & 61.10 & 61.50 & 42.60 & 62.50 \\
\hline
\end{tabular}

There was no significant difference between RYGB and VSG for excess BMI lost at 1 or 5 years or for comorbidity resolution at 5 years. ${ }^{15}$

RYGB, Roux-en-Y gastric bypass; T2DM, type 2 diabetes mellitus; VSG, vertical sleeve gastrectomy. 

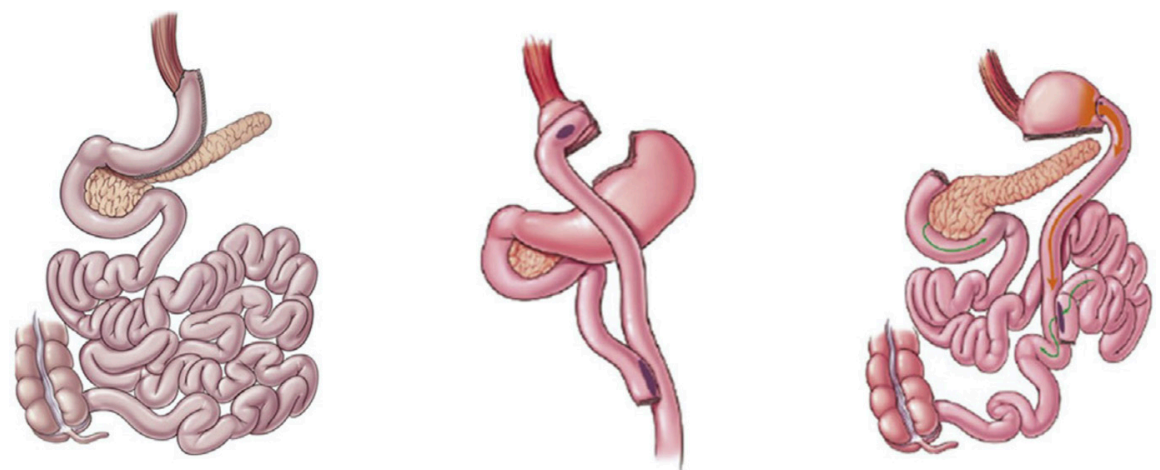

\section{Sleeve gastrectomy $\quad$ Roux-en-Y Gastric Bypass $\quad$ BPD}

Figure 2 Schematic diagram of bariatric operations. BPD, biliopancreatic diversion with duodenal switch. Adapted from ${ }^{16}$.

RYGB. ${ }^{21}$ Early ( $<30$ days) complications that are fatal include sepsis from anastomotic leak, haemorrhagic hypovolaemic shock and cardiopulmonary events such as venous thromboembolism. ${ }^{16}$

\section{Late complications (>30days)}

Late complications are procedure specific (table 9). Obstructive symptoms following RYGB may be secondary to a gastro-jejunal anastomotic stricture while after VSG may suggest narrowing at the gastrooesophageal junction or incisura angularis which can present as gastric outlet obstruction. ${ }^{22}$ Endoscopic dilatation can be used to treat upper gastrointestinal stenosis. $^{22}$ Internal herniation can also present with obstructive symptoms and is more likely following RYGB. $^{22}$ Early recognition is required to avoid lifethreatening bowel ischaemia. An abdominal computerised tomography scan is the most sensitive investigation and urgent surgical intervention is needed to reduce the hernia and resect non-viable bowel. ${ }^{16}$ At the site of the gastro-jejunostomy following RGYB, ulceration of the unprotected jejunum is due to gastric acid. ${ }^{16}$ The incidence of these marginal ulcers is $8 \%$ and the majority are treated medically, with proton pump inhibitors, but non-healing symptomatic ulcers

Table 8 Selected physiological changes following RYGB and VSG that are implicated in weight loss and improvements in postprandial glucose metabolism. Adapted from ${ }^{19}$

\begin{tabular}{lll} 
& RYGB & VSG \\
\hline Glucagon-like peptide-1 & $\uparrow \uparrow$ & $\uparrow$ \\
Peptide YY 3-36 & $\uparrow \uparrow$ & $\uparrow$ \\
Ghrelin & $\downarrow$ & $\downarrow \downarrow$ \\
Glucose-dependent & $\downarrow$ & - \\
insulinotropic polypeptide & & - \\
Oxyntomodulin & $\uparrow$ & - \\
Neurotensin & $\uparrow$ & $\uparrow$ \\
Bile acids & $\uparrow$ & - \\
Gut microbiota composition & 'Lean' phenotype & - \\
Vagal afferent signalling & $\uparrow$ & $\uparrow$ \\
\hline RYGB, Roux-en-Y gastric bypass; VSG, vertical sleeve gastrectomy.
\end{tabular}

may require surgery. ${ }^{16}$ Importantly, RCT and observational data demonstrate that GORD is observed more frequently following VSG compared to RYGB ${ }^{15} 16$.

\section{Nutritional complications}

Essential vitamin and mineral deficiencies are likely following bariatric procedures, especially RYGB and BPD and their general biochemical monitoring and lifelong supplementation are outlined (tables 10 and $11^{2324}$ ). Prolonged vomiting is a risk factor for thiamine deficiency, which can manifest as Wernicke's encephalopathy. This should be promptly treated, to avoid irreversible neurological deficits, with intravenous thiamine making sure to avoid intravenous glucose containing solutions which can exacerbate thiamine deficiency and precipitate Korsakoff's psychosis. $^{25}$

\section{Dumping syndrome}

Dumping syndrome can affect up to $50 \%$ of patients post-RYGB ${ }^{16}$. Early dumping presents with gastrointestinal symptoms (abdominal pain, nausea, diarrhoea) and sympathetic nervous system features (tremors, sweating, dizziness, tachycardia) within 15 min of eating large amounts of refined sugars and eating too quickly. These symptoms develop because of rapid emptying of food into the small

\begin{tabular}{|c|c|}
\hline Operation & Late complications \\
\hline RYGB & $\begin{array}{l}\text { Gastro-jejunal anastomotic marginal ulcer ( } 8 \% \text { ), } \\
\text { gastro-jejunal anastomtic stricture ( } 7 \% \text { ), malnutrition of } \\
\text { vitamins and minerals (up to } 50 \% \text { ), dumping syndrome } \\
\text { (up to } 50 \% \text { ), gallstones (symptomatic in } 2 \% \text { ), internal } \\
\text { hernia or small bowel obstruction (4\%). }\end{array}$ \\
\hline VSG & $\begin{array}{l}\text { Gastro-oesophageal reflux disease (33\%), gastric } \\
\text { dilatation, gastric stenosis leading to gastric outlet } \\
\text { obstruction (1-4\%), gastric leak. }\end{array}$ \\
\hline
\end{tabular}

Prevalence where known is included in brackets.

RYGB, Roux-en-Y gastric bypass; VSG, vertical sleeve gastrectomy. 
Table 10 Haematological and biochemical blood test monitoring schedule following vertical sleeve gastrectomy, roux-en-Y gastric bypass and bilopancreatic diversion with duodenal switch ${ }^{2324}$.

\begin{tabular}{|c|c|c|}
\hline Blood test & Vertical sleeve gastrectomy & $\begin{array}{l}\text { Roux-en-Y gastric bypass } \\
\text { Bilopancreatic diversion with duodenal switch }\end{array}$ \\
\hline Full blood count & At 3,6 and 12 months in the first year, annually thereafter & At 3,6 and 12 months in the first year, annually thereafter \\
\hline Urea and electrolytes & At 3,6 and 12 months in the first year, annually thereafter & At 3,6 and 12 months in the first year, annually thereafter \\
\hline Liver function & At 3,6 and 12 months in the first year, annually thereafter & At 3,6 and 12 months in the first year, annually thereafter \\
\hline $\begin{array}{l}\text { Iron studies, Folate, } \\
\text { Ca2+, Vit D, PTH }\end{array}$ & At 3,6 and 12 months in the first year, annually thereafter & At 3,6 and 12 months in the first year, annually thereafter \\
\hline Vitamin $B_{12}$ & $\begin{array}{l}6 \text { monthly first year, annually thereafter. Consider sooner if } \\
\text { anaemia or peripheral neuropathy } \\
\text { No need to monitor if receiving intramuscular B12 injections }\end{array}$ & $\begin{array}{l}6 \text { and } 12 \text { months in first year, annually thereafter. Consider sooner if } \\
\text { anaemia or peripheral neuropathy } \\
\text { No need to monitor if receiving intramuscular B12 injections }\end{array}$ \\
\hline Zinc, copper & Not routinely & $\begin{array}{l}\text { Annually. Consider sooner if unexplained anaemia, hair loss, change } \\
\text { in taste acuity, poor wound healing }\end{array}$ \\
\hline Selenium & Not routinely & $\begin{array}{l}\text { Not routinely. Consider if unexplained fatigue, anaemia, metabolic } \\
\text { bone disease, diarrhoea, heart failure }\end{array}$ \\
\hline Vitamin A & Not routinely & $\begin{array}{l}\text { Annually for BPD-DS. Consider in RYGB if steatorrhoea or night } \\
\text { blindness }\end{array}$ \\
\hline Vitamin $\mathrm{E}, \mathrm{K}$ & Not routinely & $\begin{array}{l}\text { Not routinely. Consider if unexplained anaemia, peripheral } \\
\text { neuropathy, coagulopathy }\end{array}$ \\
\hline
\end{tabular}

BPD-DS, bilopancreatic diversion with duodenal switch; Ca2+, calcium; PTH, parathyroid hormone; RYGB, roux-en-Y gastric bypass; Vit D, vitamin D.

bowel followed by rapid fluid shifts due to the hyperosmolar food content. Early dumping is often self-limiting. ${ }^{16}$ Late dumping or hyperinsulinaemic hypoglycaemia is less common and can present 1 to 3 hours after eating a high glycaemic index carbohydrate meal with neuroglycopenic symptoms. Eating small frequent meals containing low glycaemic index carbohydrates and protein whilst avoiding high glycaemic index carbohydrates is key in early and late dumping syndrome. ${ }^{16}$ Medications can be used in refractory late dumping syndrome (eg, diazoxide, octreotide, nifedipine). ${ }^{16}$

\section{Future considerations}

Gastroenterology has a key role to play in the future of obesity research and management through the human microbiome and endobariatric interventions.

The human microbiome has been implicated in obesity pathogenesis because gut micro-organisms play a key role in host energy metabolism and immunity. ${ }^{26}$ Metagenomics data have shown that obese mice and humans have higher populations of Firmicutes and lower populations of Bacteroidetes compared with lean equivalents. ${ }^{26}$ This combination is associated with more efficient energy harvesting of substrates (eg, short chain fatty acids) from non-digestible carbohydrates and upregulation of genes that enable substrates to be stored as lipids or carbohydrates. ${ }^{26}$ The human gut microbiota is differentially altered following RYGB and VSG although more profoundly and favourably after RYGB despite similar weight loss. ${ }^{19}{ }^{26}$ There is consistent data showing that faecal microbial transplantation from post-RYGB rodents and humans to recipient germ-free mice is associated with reduced adiposity and increased energy expenditure but whether these changes are essential for the metabolic benefits of bariatric surgery remain to be elucidated ${ }^{19}$.

Table 11 General vitamin and mineral supplementation recommendations following vertical sleeve gastrectomy (VSG), roux-en-Y gastric bypass (RYGB) and bilopancreatic diversion with duodenal switch (BPD-DS) 2324

\begin{tabular}{|c|c|}
\hline Supplementation & VSG/RYGB/BPD-DS \\
\hline Multivitamin & Once or twice daily over the counter multivitamins \\
\hline Iron & Once daily $200 \mathrm{mg}$ ferrous sulphate or $210 \mathrm{mg}$ ferrous fumarate (twice daily for mensturating females) \\
\hline Folic acid & Supplement only if deficient \\
\hline Vitamin $B_{12}$ & 3-monthly intramuscular 1 mg hydroxocobalamin \\
\hline Calcium and vitamin D & $\begin{array}{l}\text { Continue with pre-operative maintenance dose. Likely require } 800 \mathrm{mg} \text { calcium and } 20 \mu \mathrm{g} \text { vitamin D (eg, Adcal D3). } \\
\text { Many patients will liklely need additional vitamin D. }\end{array}$ \\
\hline Zinc and copper & Not routinely. If additional zinc needed, ratio of 8 to $15 \mathrm{mg}$ per $1 \mathrm{mg}$ copper must be maintained \\
\hline Thiamine & $\begin{array}{l}\text { Not routinely. If prolonged vomiting prescribe thiamine } 200-300 \mathrm{mg} \text { daily, vitamin B costrong } 1-2 \text { tablets and urgent } \\
\text { referral to bariatric centre. Intravenous thiamine if symptomatic. }\end{array}$ \\
\hline
\end{tabular}

Individualised supplementation regimes may be needed for some patients or patient subgroups (e.g., pregnant women). 
Table 12 Description and weight loss associated with endoscopic bariatric interventions ${ }^{27}$

\begin{tabular}{|c|c|c|c|c|}
\hline Site of action & Endoscopic intervention & Endoscopic mechanism & Description & $\begin{array}{l}\text { Excess weight loss at } 6 \text { or } \\
12 \text { months }\end{array}$ \\
\hline \multirow[t]{5}{*}{ Stomach } & \multirow[t]{3}{*}{ Intragastric balloon } & \multirow{3}{*}{$\begin{array}{l}\text { Reduction in gastric } \\
\text { volume }\end{array}$} & \multirow{3}{*}{$\begin{array}{l}\text { Endoscopic placement of balloons } \\
\text { (Orbera or Reshape) that are filled } \\
\text { with } 400-700 \text { mls of blue saline } \\
\text { which are removed after } 6 \text { months. } \\
1-3 \text { gas-filled balloons (obalon) } \\
\text { are swallowed sequentially over a } \\
12 \text {-month period and are removed } \\
\text { after } 3 \text { months. }\end{array}$} & $25 \%-32 \%$ at 12 months (orbera) \\
\hline & & & & $\begin{array}{l}27 \%-31 \% \text { at } 6 \text { months } \\
\text { (Reshape) }\end{array}$ \\
\hline & & & & $\begin{array}{l}25 \% \text { at } 6 \text { months (Obalon - not } \\
\text { available on the NHS) }\end{array}$ \\
\hline & $\begin{array}{l}\text { Endoscopic sleeve } \\
\text { gastroplasty }\end{array}$ & & $\begin{array}{l}\text { Endoscopic staples or sutures applied } \\
\text { along greater curvature of the } \\
\text { stomach to reduce gastric volume } \\
\text { by } 70 \% \text {. }\end{array}$ & $28 \%-52 \%$ at 12 months \\
\hline & Aspiration therapy & $\begin{array}{l}\text { Aspiration of gastric } \\
\text { contents }\end{array}$ & $\begin{array}{l}\text { Endoscopic placement of a } \\
\text { specialised } 26 \mathrm{Fr} \text { gastrostomy tube } \\
\text { that is used to flush water into the } \\
\text { stomach before aspirating gastric } \\
\text { contents } 20-30 \text { mins after a meal }\end{array}$ & $49 \%-54 \%$ at 12 months \\
\hline \multirow[t]{2}{*}{ Small intestine } & $\begin{array}{l}\text { Small bowel endobarrier } \\
\text { sleeve }\end{array}$ & Bypass small bowel & $\begin{array}{l}\text { A } 60 \mathrm{~cm} \text { nutrient-impermeable sleeve } \\
\text { that extends from the duodenal bulb } \\
\text { to the distal jejunum and remains in } \\
\text { for a maximum of } 12 \text { months }\end{array}$ & $35 \%$ at 12 months \\
\hline & $\begin{array}{l}\text { Duodenal mucosal } \\
\text { resurfacing }\end{array}$ & Duodenal exclusion & $\begin{array}{l}\text { Hydrothermal ablation using a } 2 \mathrm{~cm} \\
\text { long balloon filled with } 90^{\circ} \mathrm{C} \text { heated } \\
\text { fluid destroys superficial duodenal } \\
\text { mucosa distal to the papilla of Vater } \\
\text { up to the ligament of Treitz. }\end{array}$ & $2.5 \%$ at 12 months \\
\hline
\end{tabular}

Although bariatric surgery is safe, effective and cost-effective it is not a practical strategy to treat the epidemic levels of obesity. Endoscopic bariatric interventions could be an alternative for unwilling or unsuitable surgical candidates as well as an adjunct to medical therapy. Endobariatric procedures are performed under monitored anaesthetic care and target either the stomach or small bowel (table 12). ${ }^{27}$

A recent multicentre prospective study $(n=36)$ evaluating endoscopic duodenal mucosal resurfacing demonstrated that this procedure was safe, well tolerated and efficacious in reducing glycated haemoglobin by $10 \pm 2 \mathrm{mmol} / \mathrm{mol}$ (mean \pm standard error) at 12 months despite only modest weight loss of $2.5 \pm 0.6 \mathrm{~kg}$ which suggests that the improvement in glycaemia is partly weight loss independent. ${ }^{28}$ More data is needed to evaluate long-term weight loss, glycaemic changes, safety and non-weight dependent mechanisms associated with endobariatrics.

\section{CONCLUSIONS}

Gastrointestinal and hepatic diseases are often the first manifestations of obesity. Gastroenterologists and hepatologists will be at the forefront of obesity management and have a unique opportunity to implement timely weight loss interventions or refer to specialist weight management centres. With more patients meeting the criteria for bariatric surgery, awareness of the post-operative complications is essential. Finally, the potential to manipulate the human microbiome or use the increasing array of endoscopic technologies will allow for less-invasive tools to be added to the armamentarium in tackling obesity, with gastroenterologists set to be key players.

Contributors $\mathrm{NH}$ and $\mathrm{HH}$ developed the idea for the article. $\mathrm{NH}$ developed the structure for the article. SA wrote the article under the supervision of $\mathrm{NH}$ and $\mathrm{HH}$. $\mathrm{NH}$ and $\mathrm{HH}$ edited the article.

Funding The authors have not declared a specific grant for this research from any funding agency in the public, commercial or not-for-profit sectors.

Competing interests None declared.

Patient consent for publication Not required.

Provenance and peer review Not commissioned; externally peer reviewed.

ORCID iD

Saleem Ansari http://orcid.org/0000-0002-3910-7150

\section{REFERENCES}

1 Baker C.Briefing Paper 3336. Obesity statistics; 2018: 1-18.

2 Nishida C, Barba C, Cavalli-Sforza T, et al. Appropriate body-mass index for Asian populations and its implications for policy and intervention strategies. Lancet 2004;363:157-63.

3 Haase CL, Schnecke V, Eriksen KT. Bmi and risk of obesityrelated outcomes in a large UK population-representative cohort: a CPRD/HES study. European Congress on Obesity; 28/4/2019 - 01/05/2019, Glasgow, 2019:32.

4 Bhaskaran K, Dos-Santos-Silva I, Leon DA, et al. Association of BMI with overall and cause-specific mortality: a population- 
based cohort study of 3.6 million adults in the UK. Lancet Diabetes Endocrinol 2018;6:944-53.

5 Cancer Research UK. Obesity, weight and cancer | cancer research UK, 2019. Available: https://www.cancerresearchuk. org/about-cancer/causes-of-cancer/obesity-weight-and-cancer [Accessed 05/08/2020].

6 Simon GE, Von Korff M, Saunders K, et al. Association between obesity and psychiatric disorders in the US adult population. Arch Gen Psychiatry 2006;63:824-30.

7 Camilleri M, Malhi H, Acosta A. Gastrointestinal complications of obesity. Gastroenterology 2017;152:1656-70.

8 Schwartz MW, Seeley RJ, Zeltser LM, et al. Obesity pathogenesis: an endocrine Society scientific statement. Endocr Rev 2017;38:267-96.

9 Elliott JA, Reynolds JV, le Roux CW, et al. Physiology, pathophysiology and therapeutic implications of enteroendocrine control of food intake. Expert Rev Endocrinol Metab 2016;11:475-99.

10 National Institute for clinical excellence. Obesity: identification, assessment and management of overweight and obesity in children young people and adults. London; 2014.

11 Castelnuovo G, Pietrabissa G, Manzoni GM, et al. Cognitive behavioral therapy to aid weight loss in obese patients: current perspectives. Psychology Research and Behavior Management 2017;10:165-73.

12 National Institute of Clinical Excellence. Type 2 diabetes treatment summary BNF content published by NICE, 2019. Available: https://bnf.nice.org.uk/treatment-summary/type-2diabetes.html

13 Bray GA, Heisel WE, Afshin A, et al. The science of obesity management: an endocrine Society scientific statement. Endocr Rev 2018;39:79-132.

14 Sjöström L. Review of the key results from the Swedish Obese Subjects (SOS) trial - a prospective controlled intervention study of bariatric surgery. J Intern Med 2013;273:219-34.

15 Peterli R, Wölnerhanssen BK, Peters T, et al. Effect of laparoscopic sleeve gastrectomy vs laparoscopic Roux-en-Y gastric bypass on weight loss in patients with morbid obesity. JAMA 2018;319:255-65.

16 le Roux CW, Heneghan HM. Bariatric surgery for obesity. Medical Clinics of North America 2018;102:165-82.

17 Booth HP, Khan O, Fildes A, et al. Changing epidemiology of bariatric surgery in the UK: cohort study using primary care electronic health records. Obes Surg 2016;26:1900-5.
18 Agrawal S. Bariatric and metabolic surgery, a practical guide. Switzerland: Springer International Publishing, 2016. ISBN: 978-3-319-04342-5.

19 Pucci A, Batterham RL. Mechanisms underlying the weight loss effects of RYGB and SG: similar, yet different. J Endocrinol Invest 2019;42:117-28.

20 Laursen TL, Hagemann CA, Wei C, et al. Bariatric surgery in patients with non-alcoholic fatty liver disease - from pathophysiology to clinical effects. World J Hepatol 2019;11:138-49.

21 Kumar SB, Hamilton BC, Wood SG, et al. Is laparoscopic sleeve gastrectomy safer than laparoscopic gastric bypass? A comparison of 30-day complications using the MBSAQIP data registry. Surg Obes Relat Dis 2018;14:264-9.

22 Peters C, Bonanomi G, Efthimiou E. Management of bariatric emergencies by the general surgeon. In: Agrawal S, ed. Obesity, bariatric and metabolic surgery, 2016: 661-72.

23 Moore M, Hopkins J, Wainwright P. Primary care management of patients after weight loss surgery. BMJ 2016;352:i945-6.

24 O'Kane M, Pinkney J, Aasheim E, et al. Bomss guidelines on perioperative and postoperative biochemical monitoring and micronutrient replacement for patients undergoing bariatric surgery. Br Obes Metab Surg Soc 2014:1-29.

25 Kushner RF, Cummings S, Herron DM. Bariatric surgery: Postoperative nutritional complications. In: D Jones, W Chen, eds. UpToDate, 2020. https://www.uptodate.com/contents/ bariatric-surgery-postoperative-nutritional-management

26 Liu H, Hu C, Zhang X, et al. Role of gut microbiota, bile acids and their cross-talk in the effects of bariatric surgery on obesity and type 2 diabetes. J Diabetes Investig 2018;9:13-20.

27 Storm AC, Abu Dayyeh BK, Topazian M. Endobariatrics: a primer. Clin Gastroenterol Hepatol 2018;16:1701-4.

28 van Baar ACG, Holleman F, Crenier L, et al. Endoscopic duodenal mucosal resurfacing for the treatment of type 2 diabetes mellitus: one year results from the first international, open-label, prospective, multicentre study. Gut 2020;69:1-9.

29 Wyles SM, Ahmed AR. LRYGB: Complications - Diagnosis and Management. In: Agrawal S, ed. Obesity, bariatric and metabolic surgery: a practical guide. Switzerland: Springer, 2016: 207-30. ISBN: 978-3-319-04342-5.

30 Weiner RA, El-Sayes IA, Weiner SR. LSG: Complications - Diagnosis and Management. In: Agrawal S, ed. Obesity, bariatric and metabolic surgery. Switzerland: Springer, 2016: 259-76. ISBN: 978-3-319-04342-5. 